\title{
What is research? some suggestions and practical hints
}

\section{What is research?}

Dictionaries provide only a vague and inadequate definition of research. To put it in a nutshell, research in literature means (a) discovery of a new book and edit it, or (b) bring to notice a lost or alomost forgotten work, and attempt an appraisal of it. Another kind of research means (c) selecting two, three, or several works, and show their relationship, something which had not been noticed before. Nowadays, (d) translation of a culturally or historically significant work from a language other than English (not however from any intermediate language) into English with an Introduction and copious notes is also admitted as a doctoral dissertation. In any case, research involves something original, some valuable addition to the existing store of knowledge, not just a rehash of already existing views.

After one has opted for one of the above, the second step is to write down the findings in an academically approved format (such as the MLA style, Chicago Manual, etc.), following a particular style of presentation, divided into several chapters, and appendixes (optional). Sources of all quotations are to be stated, either in the text itself or in footnotes/endnotes. Finally, there must be a bibliography/a list of Works Cited, i.e., full publication details of books and periodicals and other sources, both print and electronic. One must also enlist audiovisual matters one has consulted and referred to in the text and notes. In order to avoid unnecessary troubles and subsequent embarrassment, every researcher should - must - learn to type out and proofread her/ his copy of the thesis and papers.

\section{How to write papers, dissertations, etc \\ Selection of topics}

Professor Stephen N. Hay (University of Chicago) told David Kopf, his PhD student, 'Selecting the major theme of your first work of scholarship is like selecting a wife. In either case, the better the choice, the more enduring and fruitful the relationship.' (Preface, David Kopf, British Orientalism and the Bengal Renaissance 17731835 (Chicago: University of Chicago Press, 1969). Dr Horst von Schliermann, a German-American professor, used to tell his students, "The first topic you settle upon should be narrowed three to four times." He explained: If, for example, you chose as your topic the 'Civil War,' [the American Civil War, 1861-1865] you would be almost sure to fail because you could not possibly do justice to such a large topic-dozens of books would be necessary to cover that subject, not a fifty-page paper. Remember, the title of your paper is a promise. It's like a contract in which you promise to deliver something specific. Even a second narrowing of the topic to 'The Battle of Gettysburg,' a single battle of the war would still be too large; though by subjecting the topic to a third narrowing such as 'The Battle of Cemetery Ridge,' you'd have come closer to manageability, the topic would still be too big; so perhaps a fourth narrowing such as 'The Tactical Importance of Cemetery Ridge' would be necessary. This would be a topic on which much data could be found and one on which a paper could be written in depth.
Volume 3 Issue I - 2019

\author{
Ramkrishna Bhattacharya \\ Fellow, Pavlov Institute, India
}

Correspondence: Ramkrishna Bhattacharya, Pavlov Institute, India, Email ramkrishna.bhattacharya@gmail.com

Received: December 21, 2018 | Published: January 23, 2019

\section{A librarian advised a graduate student}

If a student in his first year chooses an area carefully and continues throughout his four years in college to research and to write on topics within that area, he could, in all probability, become an outstanding expert.

(W. Pauk, "The research paper: time and technique," Journal of Reading (1969)).

\section{How to take notes?}

A Reference librarian asked the student mentioned above if he knew the advantages of recording his notes on 3 X 5 inch cards. She told him that unless he was able to categorize his notes they would become unmanageable and burdensome. Her specific suggestions were as follows:

a. First, record but one point, or a small cluster of several related points on one card;

b. Second, write a subject-matter label atop each card;

c. Third, use but one side of the card;

d. Fourth, each card should bear the title and page number of the source;

e. Fifth, put all verbatim material in quotes;

f. Sixth, almost all of the notes should be in your own word;

g. Seventh, whenever a thought or insight which is your own occurs, jot it down in the pertinent part of your notes and enclose it in square brackets [] to signify "my own".

h. (W. Pauk, "The research paper: time and technique," Journal of Reading (1969)).

No draft or its rejected part is ever to be torn up, thrown out or burnt down or destroyed for good in any way. You never can tell which rejected part or crossed-out passage might prove useful at the end of the day.

\section{Reading and writing must go on simultaneously}

This is what a prolific writer on history says about his own method of work

Laymen - that is to say, non-academic friends or friends from other academic disciplines - sometimes ask me how the historian goes to 
work when he writes history. The commonest assumption appears to be that the historian divides his work into two sharply distinguishable phases or periods. First, he spends a long preliminary period reading his sources and filling his notebooks with facts: then, when this is over, he puts away his sources, takes out his notebooks and writes his book from beginning to end. This is to me an unconvincing and unplausible picture. For myself, as soon as I have got going on a few of what I take to be capital sources, the itch becomes too strong and I begin to write - not necessarily at the beginning, but somewhere, anywhere. Thereafter, reading and writing go on simultaneously. The writing is added to, subtracted from re-shaped, cancelled, as I go on reading. The reading is guided and directed and made fruitful by the writing: the more I write, the more I know what I am looking for, the better I understand the significance and relevance of what I find. Some historians probably do all this preliminary writing in their head without using pen, paper, or typewriter, just as some people play chess in their heads without recourse to board and chessmen: this is a talent which I envy, but cannot emulate. But I am convinced that, for any historian worth the name, the two processes of what economists call 'input' and 'output' go on simultaneously and are, in practice, parts of a single process. If you try to separate them, or to give one priority over the other, you fall into one of two heresies. Either you write scissors-and-paste history without meaning or significance; or you write propaganda or historical fiction, and merely use facts of the past to embroider a kind of writing which has nothing to do with history.

(E.H. Carr. What is History? Harmondsworth: Penguin Books, 1987, pp. 28-29)

\section{How to arrange footnotes/endnotes?}

Other than bare references to the sources from which one has quoted or alluded to, notes are meant to add some information which are not so significant as to be included in the text of the paper/dissertation but deserve mention in their own right. If the note is too long, it is better to relegate it to an appendix or even several appendixes, if necessary. A very long note, which does not match the rest of the notes, should always be avoided at all costs. Remember: neophytes provide too many notes; experienced ones try to keep the number of notes to the minimum. Follow the adage: Too many notes spoil the paper.

Here is a maxim of Winfred Lehmann: 'If it's worth saying, put it in the text; if it's worth saying but won't fit in the text, write a second article.' To this Edgar C. Polomé added: 'Footnotes can be very useful in shaping the written page so that it can be quickly and easily grasped in footnotes; the custom of writing a second monograph in footnotes should be criticized as obscurantist...'. (Book review in The Journal of Indo-European Studies, vol.24 Nos. 1\&2, Spring/Summer 1996, p.122.).

\section{Waiting for the itch}

A research scholar must develop this 'itch' for writing mentioned by Carr. S/he should be guided by what Galileo is made to say in Bertolt Brecht's play, Life of Galileo (Scene 7): 'Sometimes I think I'll have myself shut in a dungeon ten fathoms under the ground where no light penetrates, if I could thereby discover what it is - light. And the worst is that what I know I must repeat like a lover, like a drunkard, like a traitor.' ( $<$ www.arvindguptatoys.com/arvindgupta/lifeofgalileo. pdf> Trans. Desmond L. Vasey, Calcutta: Oxford University Press, 1971).

\section{Acknowledgment}

None.

\section{Conflicts of interest}

The author declares that there is no conflict of interest. 